\title{
Dividends of Security in Managing Education for the Attainment of Sustainable Development Goals in Anambra State
}

\author{
Stella Nkechi Ezeaku \\ Department of Educational Foundations, Chukwuemeka Odumegwu Ojukwu University, Ihiala, Nigeria
}

Email address:

drezeakustella@gmail.com

To cite this article:

Stella Nkechi Ezeaku. Dividends of Security in Managing Education for the Attainment of Sustainable Development Goals in Anambra State. International Journal of Education, Culture and Society. Vol. 4, No. 4, 2019, pp. 60-64. doi: 10.11648/j.ijecs.20190404.11

Received: June 26, 2019; Accepted: July 30, 2019; Published: August 26, 2019

\begin{abstract}
The paper investigated dividends of security in managing education for the attainment of sustainable development goals in Anambra State, Nigeria. Three research questions were answered and a null hypothesis tested. The population was all principals and teachers in Anambra State. Post Primary Schools Service Commission (P.P.S.S.C.) numbering 5,566 200 respondents consisting of 50 principals and 150 teachers were used. A structured self-developed questionnaire was used for data collection. Data were analysed with mean and t-test at .05 level of significance. Major findings of the study included teacher-related problems caused by lack of security, principals-related problems of insecurity and strategies towards realizing sustainable development goals. The study concluded that effective security will go a long way in helping the attainment of Sustainable Development Goals. Based on the findings, it was recommended among others the need for better funding of security projects and sensitization of the public to be more security conscious because security demands collective efforts for it to be effective.
\end{abstract}

Keywords: Dividends, Security, Education \& Sustainable Development

\section{Introduction}

No country can grow and develop without an effective and efficient security set-up. Total chaos will always prevail in the face of insecurity. Jones defined security as a state of being safe from dangers such as armed robbery attacks or terrorist attacks [1]. According to him, security is synonymous with "protection", "safety" and "orderliness". Ingramstressed that security is the prevalence of positive living conditions chiefly characterized by safety of lives and properties at all times so much so that citizens can fully enjoy socio-economic and political development [2]. The issue of security in Nigeria,since independence, had been a topical one due to the level of insecurity obtainable in the country. The security situation in Nigeria is somehow complicated and needs careful appraisal. The state of security or insecurity in a country has profound effects on social realities in the society at large. Education is one area that needs to blossom under the best of conditions.

The overall importance of education to national growth and development cannot be over-stressed. Perhaps this prompted Fafunwato state that education is the best defence of any nation and any amount of money spent on education is money well-spent [3]. Supporting the above contention, Briggs posited that education is a long-term investment by the state to make itself a better place in which to live and a better place in which to make a living [4]. Further, Thompsonasserted that education has become a pragmatic instrument for national development since it constitutes a device for achieving various goals and objectives of any society as no nation can afford to be ignorant of education and be free [5]. Having underlined the importance of education to mankind, there is need to briefly look at the gains of education. Watsonidentified dividends of modern education to include manpower development, rural regeneration, national integration, economic emancipation, democratic government among others [6]. Ekanem stated that education is the basic human right that should be feasibly accorded to all human beings since it is the key index to economic and social development of a nation [7]. Further, 
Agbowuroet. al.asserted that education is first and foremost a basic need which any ambitious country must embrace in a bid to reach optimum development [8]. However, to realize these dividends, the education system has to be both functional and qualitative. It will be an exaggeration to categorically state that Nigeria's education system is perfect. If anything, it is defective and totally incapable of helping the country go to the next level. Perhaps this prompted Animasaunto inform that a state of emergency has to be declared on the educational system so that for three years all emphasis must be on educational sector to the neglect of other sectors [9]. For the situation tobe reversed, there is need to ensure a good security set up capable of promoting a conducive environment for socio-economic development.

Commenting on Nigeria's security situation, Pikestated that in the $1980 \mathrm{~s}$, serious crime grew to nearly epidemic proportions particularly in Lagos and other urbanized areas characterized by rapid growth and change, stark economic inequality and deprivation, social disorganization, inadequate government service and law enforcement capabilities [10]. According to him, in the late 1980 s, the crime wave was exacerbated by worsening economic conditions and by the ineffectiveness, inefficiency and corruption of police, military and customs personnel who colluded and conspired with criminals or actually engaged in criminal conduct. This takes us to sustainable development. Kundan in Ugohdescribes sustainable development as a construct, which envision development as meeting the need of the present generation without compromising the need of the future generation [11]. According to him, it implies that while education meets the need of the present, it does not compromise the ability of the future generation to meet its own needs. He further explained that continued sustainable development is possible or assured when it is agreed and indeed concrete steps are taken to raise the level of literacy and numeracy in any society. The focus of this investigation is to determine the dividends of security in managing education for the attainment of sustainable development goals in Anambra State.

\subsection{Statement of the Problem}

A female teacher in one of the public secondary schools in Anambra State was killed in the aftermath of a vicious attack she received at the hands of relations of a student she flogged in the school. This incident is one of the many unfortunate incidents befalling teachers in their place of work. If you add this type of intimidation to the exploits of cult groups who terrorize teachers and fellow student alike then one begins to visualize the mortal dangers teachers are placed in the process of imparting knowledge to students. This unfortunate trend is giving stakeholders to education anxious moments so much so that there is a genuine fear that if nothing tangible is done to check this menace, the lofty goals of secondary education will not be realized to a large extent. Cultism in particular can single-handedly disrupt school activities to the extent where teachers will be too terrified to be useful in promoting education at all levels especially secondary level.
The problem of this investigation therefore, is to determine the dividends of security in managing education for the attainment of sustainable development goals in Anambra State.

\subsection{Purpose of the Study}

Generally, the purpose of the study was to determine the dividends of security in managing education for the attainment of sustainable development goals. Specifically, the objectives of the study are to determine -

1. Teacher-related problems caused by lack of security in secondary school system.

2. Principal-related problems caused by insecurity in secondary school system.

3. Strategies towards realizing sustainable development goals through security-based educational system.

\subsection{Significance of the Study}

The findings of this investigation will be of immense benefits to teachers, principals and government. Data generated from teacher-related problems of insecurity will help teachers to know how insecurity impacts negatively on their morale and productivity. This invaluable information will help teachers to not only be aware of their security challenges on the job but also enable them to seek longlasting solutions to the problem.

Principals are not left out of people to benefit from the outcome of this investigation. They will, from data generated, be sensitive to their security challenges as principals and how it has been negatively affecting them. This knowledge will help them to proffer solutions to the identified principal-related problems. They will become more effective and efficient if they are able to identify impediments to their administrative effectiveness.

Finally, the government will be the greatest beneficiaries from the findings of the investigation. The facts generated from strategies towards reaping sustainable development goals will help them to nip the problem in the bud before it escalates. Further, they will be able to study facts revealed on teacher-related and principals-related factors caused by poor security coverage in Nigeria. The knowledge of these information will go a long way in helping the government through her Educational Planners to review the present education system in view of achieving sustainable development goals through security-based education system.

\subsection{Research Questions}

The following research questions were formulated to guide the study:

1. What are the teacher-related problems of lack of security in the secondary school system?

2. What are the principal-related problems of insecurity in the secondary school system?

3. What are the strategies towards reaping sustainable development goals through security-based educational system? 


\subsection{Hypothesis}

$\mathrm{Ho}_{1}$ There is no significant difference in the mean ratings of male and female teachers on teacher-related problems caused by lack of security in the secondary school system.

\subsection{Scope of the Study}

The study was de-limited to determining the dividends of security in managing education for the attainment of sustainable development goals in Anambra State. It covered teacher-related problems of insecurity, principals-related problems of insecurity and strategies towards reaping sustainable development goals through security-based educational system.

\section{Method}

The research design adopted for this study was Descriptive Survey. It was designed to determine the dividends of security in managing education for the attainment of sustainable development goals. Azubuike stated that survey research design examines people's opinions, motivations, interests and perception on a subject through the use of questionnaire or interview [12]. Based on this, this design was deemed appropriate for the study.

The population for the study consisted of all the secondary school principals and teachers numbering 5,566. The study made use of 200 respondents consisting of 150 teachers and 50 principals. Stratified sampling method was used to ensure that all Education Zones were represented. This agreed with the contention of Berg and Gallthat stratified sampling is important to ensure that all sub-groups in the population are represented [13]. A total of 25 teachers and 8 principals each were selected from the 6 Education Zones through balloting system. This was done with the help of Research Assistants who are fellow teachers in contact schools. On the whole, 200 respondents were used for the study.

A self-developed structured questionnaire was used for data collection and captioned, "Dividends of Security in Managing Education for Attainment of Sustainable Development Goals Questionnaire". It consisted of 15 items spread over three sections. It was validated through informed opinions of three experts from the Faculty of Education, Departments of Educational Management and Planning and Measurement and Evaluation, Universities of Nigeria, Nsukka and Nnamdi Azikiwe University, Awka. Cronbach (coefficient) Alpha formula was used to analyse the data collected for reliability. A reliability of .89 was obtained for the instrument which was very reliable. Hundred percent of the 200 questionnaire administered through on-the spot method of administration were properly completed and retrieved.

On techniques for data analysis, the research questions were analysed using the mean and standard deviation. The null hypothesis was tested using t-test. Items that attracted a mean rating of 2.50 and above were accepted and vice-versa. The t-test was used at .05 level of significance at 334 degree of freedom in testing the hypothesis for the study. The null hypothesis was not rejected if the calculated $t$-value was less than the table value, and was rejected if the calculated t-value was equal or greater than the table value.

\section{Results of Data Analysis}

Table 1. Mean responses of respondents on teacher-related problems oflack of security in the secondary school system.

\begin{tabular}{|c|c|c|c|c|}
\hline \multirow{2}{*}{$\mathbf{S} / \mathbf{N}$} & \multicolumn{2}{|l|}{ Teacher-related Problems of Lack of Security } & \multirow[t]{2}{*}{ SD } & \multirow[t]{2}{*}{ Rmks } \\
\hline & Such Problems include: & & & \\
\hline 1. & Low morale and productivity & 3.5 & 0.65 & Very Importan \\
\hline 2. & Patronage of cultism out of fear for family safety & 3.33 & 0.63 & Important \\
\hline 3. & Condonment of students' indiscipline & 3.42 & 0.64 & Important \\
\hline 4. & High attrition rate & 3.75 & 0.44 & Important \\
\hline 5. & Truancy and poor attitude to work & 3.92 & 0.28 & Very Importan \\
\hline
\end{tabular}

To a high extent, information documented on Table 1 depicted homogeneity in responses among the respondents as regards teacher-related problems of lack of security in the secondary school system.

Table 2. Mean responses of respondents on principal-related problems of insecurity in secondary school system.

\begin{tabular}{llll}
\hline \multirow{2}{*}{ S/N } & Principal-related Problems of Insecurity & & SD \\
\cline { 2 - 4 } & Such Problems include: & & Rmks \\
\hline 6. & Administrative ineptitude & 3.17 & 1.11 \\
7. & Poor level of motivation on the job & 3.25 & 0.73 \\
8. & Over-delegation of duties to subordinates & 3.5 & 0.65 \\
9. & Poor staff control & 3.83 & 0.37 \\
10. & Low morale and productivity & 3.42 & Important \\
\hline
\end{tabular}

From the tabulated result on Table 2, it is clearly revealed that there is respondents' consensus that these are principal-related problems on insecurity in secondary school system. 
Table 3. Mean responses of respondents on strategies towards reaping sustainable development goals.

\begin{tabular}{|c|c|c|c|c|}
\hline \multirow{2}{*}{$\mathbf{S} / \mathbf{N}$} & \multirow{2}{*}{\multicolumn{2}{|c|}{$\begin{array}{l}\text { Strategies towards reaping sustainable development goals } \\
\text { Such Strategies are: }\end{array}$}} & SD & Rmks \\
\hline & & & & \\
\hline 11. & Posting law enforcement agents to secondary schools for protection & 3.33 & 0.63 & Important \\
\hline 12. & Clamping down very hard on cultists & 3.17 & 0.56 & Important \\
\hline 13. & Improvement of teachers' conditions of service & 3.5 & 0.65 & Very Important \\
\hline 14. & Compulsory boarding arrangement complete with staff quarters & 3.75 & 0.44 & Important \\
\hline 15. & Weeding out of teachers with forged or dubious credentials & 3.92 & 0.28 & Very Important \\
\hline
\end{tabular}

The result tabulated on Table 3 revealed the respondents' consensus that items listed above are strategies towards realising the sustainable development goals through security-based education system.

Table 4. Shows t-test summary examining the difference in responses of male and female teachers on teacher-related problems caused by lack of security in the secondary school system.

\begin{tabular}{|c|c|c|c|c|c|c|c|}
\hline Teachers' Gender & No. of Respondents & Mean & Standard DeviationSD & Degree of Freedom & Level of significance & t-cal & t-crit \\
\hline Male Teachers & 60 & 3.14 & 0.92 & 334 & 0.5 & 0.61 & 1.96 \\
\hline Female Teachers & 90 & 3.25 & 0.79 & & & & \\
\hline
\end{tabular}

Table 4 shows that there is no significant difference between male and female teachers on teacher-related problems caused by lack of security in the secondary school system.

\section{Findings}

The following findings were made:

1. Teacher-related problems caused by lack of security are low morale and productivity, patronage of cultism out of fear for family safety, condonment of students' indiscipline, high attrition rate and truancy and poor attitude to work.

2. Principals-related problems caused by insecurity include administrative ineptitude, poor level of motivation on $t$ he job, over-delegation of duties to subordinates, poor staff control and low morale and productivity.

3. Strategies towards realizing the goals of sustainable development include need to post law enforcement agents to schools, clamping down hard on cultists, improvement of teachers' conditions of service, compulsory boarding arrangement complete with staff quarters and weeding out teachers with forged or dubious credentials.

4. The null hypothesis of no significant difference between the mean responses of male and female teachers on teacher-related problems caused by lack of security in the secondary school system was not rejected.

\section{Discussion}

The study revealed that there are teacher-related problems caused by lack of security. These include low morale and productivity, patronage of cultism out of fear of family safety, condonmentof students' indiscipline, high attrition rate and poor attitude to work. These factors, to a significant extent, result from lack of security in the secondary school system. This assertion tallies with the comment of Nnabuo and
Asodike that there is need to empower teachers to create opportunity that will enable all learners to be educated for sustainability [14]. He explained that in-service training and other opportunities for professional growth must respond to real need faced by teachers everyday as they try to achieve the objectives for which they are recruited and function for which the school is noted.

Further, the findings revealed principals-related problems caused by insecurity which include administrative ineptitude, poor level of motivation on the job, over-delegation to subordinates, poor staff control and low morale and productivity. This coincides with the contention of Macleanthat although there are many keys to development such as improved infrastructure such as dams, roads, telecommunication facilities, ports and the like, education is regarded as being the master key to economic and social development [15]. According to him, high quality and relevant education and schooling have been shown to open doors to poverty alleviation, sustainable development, equity, justice and mainstreaming of the marginalized and vulnerable groups in the society.

Finally, results from the findings revealed certain strategies towards realising sustainable development goals. These include need to post law enforcement agents to schools, clamping down hard on cultists, improved working conditions of service, compulsory boarding arrangement complete with staff quarters and weeding out teachers with forged or dubious credentials. Singly and collectively these strategies will go a long way in helping to realize goals of sustainable development in the secondary schools system. This tallies with the submission of Asodike that violent activities are deterrent to development and that investment is only possible when peace and tranquility reign and when other social vices are little known. According to Nnabuo and Asodike, this can be true where education is appropriately oriented to include moral principles, skills, perspectives and values related to sustainable development that are currently included in most education systems [16]. They explained that education must guide and motivate people to pursue 
sustainable livelihoods, to participate in a democratic society and live in a sustainable manner. Further, they stressed that education must be properly tailored to the needs of the people and properly acquired.

\section{Conclusion}

Based on the results of the findings, it is concluded that no efforts should be spared in initiating and sustaining an excellent security network capable of ensuring maximum protection of lives and properties as a sequel to socioeconomic development. This approach will surely have a positive impact on our secondary education system and thus realizing the goals of sustainable development.

\section{Recommendations}

1. There is need to place security agents in schools especially those with dormitories to avoid the incessant kidnapping, e.g. ChibokandDapchi cases.

2. Cultism in secondary schools should be rooted out through proactive measures like having vigorous anticult groups in schools.

3. Adequate funding of education to avoid making our schools a caricature of what they should be in terms of infrastructures and facilities.

4. Upgrading teachers conditions of service in order to reduce attrition rate.

5. Holding regular seminars on security in general for principals and teachers on how to tackle issues of insecurity.

\section{References}

[1] Jones, W. C. (2013) Modern Theories of Management. New York: McGraw Hill.

[2] Ingram, C. (2014) General Principles of Education. Boston: Lilly \& Ferns Inc.
[3] Fafunwa, B. (1998, June, 18th) "Education as the Best Defence”. Lagos: Vanguard, p. 24.

[4] Briggs, H. (2008) Essentials of Management and Planning in Education. London: Cox and Waxman.

[5] Thompson, V. (2010). Modern Education: A Pragmatic Approach. London: University Press.

[6] Watson, N. (2015). Aspects of Modern Education. London: Longman.

[7] Ekanem, E. J. (2015). Problems and Prospects in Education. Journal of Education and Practice. p8.

[8] Agbowuro, C., Saidu, C. \&Jimwan, C. (2017). Creative and Functional Education: The Challenges and Prospects in a Comatose Economy. Journal of Education and Practice. p8.

[9] Animasaun, B. (2000, March, 20th) "Declare State of Emergency Now!” Lagos: Vanguard, p. 24.

[10] Pike, J. (2012). Nigeria Police Force. http://www.fas.org/irp/ world/Nigeria/npf.htm. visited April 30, 2012.

[11] Ugoh, S. C. (2008). Oil Politics and Crisis of Development in the Niger Delta. Journal of Sustainable Development in Africa $10(2), 91-115$.

[12] Azubuike, F. C. (2012, March, 12th) "Dangers of Insecurity to Nigerians." Awka: National Light, p. 16.

[13] Berg, W. R. and Gall, M. D. (2004) Educational research: An Introduction. New York: Longman 5th Edition.

[14] Asodike, J. D. (2008) Analysis of Returns to Investment in Skills Acquisition Programme (SAP) In Rivers State. Unpublished Ph.D Thesis, University of Port Harcourt, Rivers State, Nigeria.

[15] Maclean, P. (2008) Education for Peace Building and Sustainable Development: Delusion, Illusion or Reality? Retrieved.

[16] Nnabuo, P. O. and Asodike, J. D. (2008) "Exploring Education as a Tool for Sustainable Development in Nigeria." European Scientific JournalVol. 8, No. 10. 